\title{
Performa Produksi Telur Turunan Pertama (F1) Persilangan Ayam Arab dan Ayam Kampung yang Diberi Ransum dengan Level Protein Berbeda
}

\author{
Husmaini dan Sabrina \\ Fakultas Peternakan Universitas Andalas Padang
}

\begin{abstract}
An experiment has been conducted to study the effect of diets with different level of protein on the production performance of offspring (F1) crossbred between arab and kampung chicken. Fifty four crossbreed hens of 20 weeks of age were used in the experiment. The hens were divided into 3 feeding groups, each $6 \times 3$ heads. Treatment diets were formulated in three different levels of protein: 15, 17 and $19 \%$. The diets which an average energy content of $2850 \mathrm{kcal} / \mathrm{kg}$ were offered for 8 weeks. Variable observed included: feed intake, hen day egg production, FCR, egg weight and color index of yellow egg. The data were statistically analyzed by variance analysis in completely block design with 3 treatments and 6 replicates. The results indicated the protein level had significant effect on all variables. Diet with $19 \%$ crude protein gave the best performance.
\end{abstract}

Key words: laying hen nutrition, protein level, Arab and kampung breed.

\section{Pendahuluan}

Ayam kampung yang lebih dikenal dengan ayam buras, merupakan ternak lokal yang telah menjadi bagian dari kehidupan masyarakat pedesaan di Indonesia. Jika dibandingkan dengan ayam ras, ayam kampung memiliki beberapa keunggulan. Harga telur dan dagingnya lebih mahal dibandingkan ayam ras. Disamping itu, ayam ini lebih tahan penyakit dan memiliki daya adaptasi yang tinggi terhadap lingkungannya, sehingga pemeliharaannya lebih mudah.

Populasi ayam kampung cukup banyak dan menyebar di seluruh daerah Indonesia. Penyebaran ayam kampung di Indonesia sebagian besar terkosentrasi di daerah pedesaan, dengan populasi 253.133.483 ekor pada tahun 1998. Kontribusi dari populasi tersebut terhadap daging mencapai 294.166 ton dan 126.254 ton untuk telur (Ditjen Peternakan, 1999) atau menyuplai $47,3 \%$ produksi daging unggas dan 23,8 \% produksi telur pada tahun tersebut.

Salah satu kelemahan ayam kampung adalah produktivitasnya yang rendah. Dalam upaya meningkatkan potensi ayam kampung perlu adanya perbaikan manajemen pemeliharaan dan perbaikan mutu genetik melalui persilangan dengan ayam yang mempunyai produktivitas tinggi.

Ayam arab merupakan ayam brakel krielsilver, dikenal sebagai ayam asli Belgia yang memiliki produktivitas telur tinggi. Telurnya menyerupai telur ayam kampung, baik dari warna, bentuk, ukuran maupun kandungan gizinya. Sedangkan dagingnya terlihat lebih padat 
dibandingkan ayam broiler, juga menyerupai daging ayam kampung dengan perlemakan sedikit, tetapi dengan warna yang lebih gelap.

Ayam arab mempunyai potensi sebagai petelur dengan produktivitas yang lebih tinggi yaitu mencapai 280 butir/tahun, jauh lebih tinggi dibandingkan ayam kampung yang hanya memproduksi telur 150 butir per tahun setelah dipelihara secara intensif. (Sarwono, 2002). Menurut Kusnindaryanto (2000), ayam arab termasuk galur ayam bukan ras unggul di Belgia. Keunggulan ayam arab ini selain produktivitasnya yang tinggi, ayam arab tidak mempunyai sifat mengeram sehingga waktu bertelurnya lebih panjang.

Upaya memperbaiki mutu genetik ayam kampung melalui persilangan dengan ayam arab diharapkan dapat dihasilkan keturunan dengan produktivitas yang tinggi, daya adaptasi dengan lingkungan yang baik serta tahan terhadap penyakit. Namun mutu genetik yang dihasilkan akan dapat tampil optimal bila diikuti dengan perbaikan lingkungan yang baik juga seperti memberikan kebutuhan pakan yang sesuai, karena penotip merupakan gabungan dari kemampuan faktor genetik dan faktor lingkungan.

Untuk memenuhi kebutuhan hidup pokok dan produksi, ayam membutuhkan ransum dan jumlah yang cukup. Ayam kampung membutuhkan protein $21 \%$ untuk periode starter, 15-19 \% untuk periode grower dan $18 \%$ untuk periode layer (Dudung, 2000). Ayam arab membutuhkan protein 15-17 \% untuk periode starter, $15 \%$ untuk periode grower dan 14-15\% untuk periode layer (Darmana dan Sitanggang, 2002).
Penelitian ini bertujuan untuk mengetahui pengaruh pemberian beberapa level protein dalam ransum terhadap performa produksi telur ayam turunan pertama (FI) persilangan ayam arab dengan ayam kampung.

\section{Materi dan Metode}

Penelitian ini menggunakan 54 ekor ayam betina dengan umur 20 minggu. Ayam ini merupakan turunan pertama (F1) hasil persilangan antara ayam arab dengan ayam kampung. Ayam dipelihara secara individu di dalam 54 unit kandang baterai dengan rukuran $40 \times 20 \times 45$ $\mathrm{cm}$. Setiap unit kandang dilengkapi dengan tempat makan dan minum.

Ransum pelakuan diaduk sendiri dan menggunakan bahan terdiri dari: jagung kuning, bungkil kelapa, bungkil kedelai, tepung ikan, tepung tulang dan minyak kelapa (Tabel 1). Ransum disusun iso energi yaitu $2850 \mathrm{Kkal} / \mathrm{kg}$ dengan kandungan protein berbeda sesuai dengan perlakuan, yaitu: 15, 17, dan $19 \%$. Komposisi bahan penyususn dan kandungan zat makanan dan energi ransum disajikan pada Tabel 1.

Rancangan yang digunakan Rancangan Acak Kelomplok (RAK) berdasarkan bobot badan dengan 3 perlakuan level protein dan 6 kelompok bobot badan sebagai ulangan. Setiap unit perlakuan terdiri dari 3 ekor.

Peubah yang diukur dalam penelitian ini adalah konsumsi ransum, produksi telur, berat telur dan warna kuning. Pengukuran dilakukan selama 8 minggu produksi. 


\section{Hasil dan Pembahasan}

Rataan Konsumsi ransum, produksi telur dan konversi ransum selama 8 minggu pengamatan disajikan pada Tabel 1 . sipnya ayam makan untuk memenuhi kebutuhan energinya. Wahyu (1992) berpendapat bahwa faktor yang mempengaruhi konsumsi ransum adalah energi ransum.

Tabel 1. Komposisi Bahan Pakan Penyusun Ransum Perlakuan (\%)

\begin{tabular}{|l|c|c|c|}
\hline \multirow{2}{*}{ Bahan Pakan } & \multicolumn{3}{|c|}{ Ransum Perlakuan dengan Kandungan Protein (\%): } \\
\cline { 2 - 4 } & 15 & 17 & 19 \\
\hline Jagung Kuning & 62,00 & 59,10 & 53,00 \\
Dedak Halus & 15,00 & 11,00 & 6,75 \\
Bungkil Kedele & 3,00 & 9,40 & 15,50 \\
Bungkil Kelapa & 2,50 & 2,50 & 5,75 \\
Tepung Ikan & 12,00 & 12,50 & 12,50 \\
Minyak Kelapa & 0,50 & 0,50 & 1,50 \\
Tepung Tulang & 5,00 & 5,00 & 5,00 \\
\hline & & & \\
& Kandungan energi dan zat makanan: & 2858,73 \\
ME ( Kkal/Kg) & 2857,80 & 2850,26 & 19,02 \\
Protein (\%) & 15,00 & 17,02 & 4,98 \\
Lemak (\%) & 4,70 & 3,81 & 3,56 \\
Serat Kasar (\%) & 3,99 & 3,65 & 2,38 \\
Ca (\%) & 2,28 & 2,34 & 1,05 \\
P (\%) & 1,04 & 1,05 & \\
\hline
\end{tabular}

Hasil analisis ragam menunjukkan bahwa tidak terdapat pengaruh yang nyata $(\mathrm{P}>0,05)$ antara level protein ransum perlakuan terhadap jumlah konsumsi ransum. Hal ini disebabkan meskipun level protein ransum berbeda tetapi ransum disusun isoenergi, padahal tujuan utama ayam mengkonsumsi ransum adalah untuk memenuhi kebutuhan energinya, dan setelah energi terpenuhi maka ayam akan berhenti makan. Menurut Oluyemi and Roberts (1979) konsep ini didasari oleh kemampuan ayam untuk mengatur intake energinya melalui sitem syaraf di hypothalamus, dimana prin-
Dari Tabel 1 diketahui bahwa rataan konsumsi ransum ayam turunan pertama persilangan ayam kampung dan ayam arab adalah $3 \quad 830,27$ gram/ekor atau setara dengan 68,40 gram/ekor/hari. Rataan konsumsi ransum penelitian ini mendekati konsumsi ransum ayam arab yaitu 70 - 80 gram/ekor (Sarwono, 2001) tetapi jauh lebih rendah dibandingkan konsumsi ayam kampung yaitu 95 gram/ekor pada umur yang sama (Deptan, 1999).

Hasil analisis ragam peubah produksi telur (hen day production) ayam turunan (F1) persilangan ayam arab dengan ayam kampung mem- 
perlihatkan tidak terdapat pengaruh yang nyata $(\mathrm{P}>0,05)$ perlakuan level protein ransum dengan hen day production selama 8 minggu pengamatan. Hal ini disebabkan kemampuan genetis ayam hasil persilangan ini berada diantara kemampuan genetis tetuanya yaitu ayam arab dan ayam kampung. Menurut Rasyaf (1991) walaupun banyak yang mempengaruhi produksi telur, secara genetis setiap unggas mempunyai batas kemampuan maksimal dalam berproduksi.

Dari Tabel 2 terlihat bahwa, pemberian ransum dengan level protein yang lebih tinggi dapat meningkatkan hen day production tetapi peningkatan produksi telur yang dihasilkan belum menunjukkan perbedaan yang nyata secara statistik.

Pada penelitian ini pemberian level protein ransum $19 \%$ dalam ransum pada penelitian ini diperoleh ransum yang dikonsumsinya. Pada penelitian ini, meskipun jumlah konsumsi ransum sama, tetapi akibat perbedaan level protein maka protein yang terkonsumsi juga akan berbeda yaitu perlakuan $\mathrm{A}=10,25 \mathrm{gram} / \mathrm{hari}$; $\mathrm{B}=11,73 \mathrm{gram} / \mathrm{hr}$ dan $\mathrm{C}=12,89$ gram.

Tingkat produksi telur (HD) ayam turunan pertama persilangan ayam arab dengan ayam kampung pada penelitian rata-rata adalah 47,22 $\%$, dengan demikian persilangan ayam kampung dengan ayam arab yang mempunyai tingkat produksi mencapai $70 \%$ perhari (Sarwono, 2001) telah dapat memperbaiki tingkat produksi ayam kampung. Dari penelitiaan Abbas (1988) diketahui bahwa rata-rata produksi ayam kampung petelur pada usaha peternakan rakyat di Sumatera Barat adalah $36,30 \%$.

Tabel 2. Rataan Konsumsi Ransum, Produksi Telur (HD) dan Konversi Ransum Masing-masing Perlakuan Selama 8 Minggu Penelitian

\begin{tabular}{|c|c|c|c|}
\hline Perlakuan & $\begin{array}{c}\text { Konsumsi } \\
\text { Ransum } \\
\text { (gram/ekor) }\end{array}$ & $\begin{array}{c}\text { Produksi Telur } \\
\text { (Hen day, \%) }\end{array}$ & Konversi Ransum \\
\hline A ( 15\%) & 3826,95 & 43,65 & 4,47 \\
B ( 17\%) & 3863,35 & 45,44 & 4,39 \\
C ( 19\%) & 3800,52 & 52,58 & 3,49 \\
\hline Rataan & 3830,27 & 47,22 & 4,12 \\
\hline SE & 19,61 & 4,18 & 0,796 \\
\hline
\end{tabular}

produksi telur paling tinggi yaitu $52,58 \%$.

Menurut Sudaryani dan Santoso (1994) untuk mendapatkan produksi telur yang tinggi dibutuhkan tingkat konsumsi protein yang lebih tinggi pula, karena untuk membentuk sebutir telur juga diperlukan sejumlah protein yang diperoleh ayam melalui
Hasil analisis ragam konversi ransum menunjukkan bahwa tidak ada pengaruh yang nyata $(\mathrm{P}>0,05)$ pemberian level protein ransum terhadap konversi ransum. Hal ini disebabkan konsumsi ransum dan produksi telur juga tidak berbeda nyata sedangkan konversi ransum merupakan perbandingan antara 
konsumsi ransum dengan jumlah produksi telur dalam satuan berat yang sama. Meskipun demikian, dari Tabel 2 terlihat bahwa ada kecenderungan peningkatan level protein dalam ransum dapat menekan konversi ransum menjadi lebih baik. Pemberian level protein $19 \%$ dapat menghasilkan konversi ransum paling rendah yaitu 3,49.

Rataan konversi ransum ayam turunan pertama persilangan ayam arab dengan ayam kampung pada penelitian ini adalah 4,12. Menurut Abbas (1988), konversi ransum ayam kampung petelur di Sumatera Barat ini adalah 5,22, sedangkan konversi ransum ayam arab (hasil perhitungan) adalah 2,38 (Sarwono, 2001). Hal ini menunjukkan bahwa persilangan ayam kampung dengan ayam arab dapat memperbaiki konversi ayam kampung dari 5,22 menjadi 4,12 karena kemampuan genetis hasil persilangan berada diantara tetuanya.

Rataan berat telur dan warna kuning telur menurut masing-masing perlakuan dapat dilihat pada Tabel 3.

Dari hasil analisa keragaman ternyata perlakuan memberikan pengaruh yang tidak berbeda nyata
$(\mathrm{P}>0,05)$ terhadap berat, warna kuning dan indeks telur disebabkan jumlah protein perlakuan terhadap (A) yang diberikan talah mencukupi kebutuhan untuk produksi optimal, sesuai dengan pendapat Sugandhi (1973), bahwa peningkatan kandungan protein dengan kandungan energi yang sama dalam ransum dapat meningkatkan produksi telur, tetapi peningkatan protein ransum dalam batas tertentu tidak berpengaruh terhadap berat telur bila kebutuhannya sudah terpenuhi. Secara biologis dari perlakuan A ke B terjadi peningkatan berat telur, akan tetapi pada perlakuan $\mathrm{C}$, berat telur menurun, hal ini disebabkan pada perlakuan $\mathrm{C}$ terjadi peningkatan jumlah produksi harian, sehingga akan menurunkan berat telur.

Rataan berat telur pada penelitian ini adalah 37,92 gram/butir. Menurut Darmana dan Sitanggang (2002) berat telur ayam arab adalah 40 gram per burtir sedangkan berat telur ayam kampung adalah 34,8945,49 gram per butir (Jasman, 1989). Dengan demikian terlihat bahwa berat telur ayam hasil persilangan ayam arab dengan ayam kampung berada diantara tetuanya.

Tabel 3. Rataan Berat Telur dan Warna Kuning Telur Menurut Masing-masing Perlakuan

\begin{tabular}{|c|c|c|}
\hline Perlakuan & $\begin{array}{c}\text { Rataan Berat Telur } \\
\text { (gr/butir })\end{array}$ & $\begin{array}{c}\text { Rataan Warna Kuning } \\
\text { Telur }\end{array}$ \\
\hline A ( 15\%) & 37,87 & 9,80 \\
B ( 17\%) & 38,51 & 9,75 \\
C ( 19\%) & 37,37 & 9,33 \\
\hline Rataan & 37,92 & 9,62 \\
\hline SE & 1,09 & 0,24 \\
\hline
\end{tabular}


Hasil analisis ragam warna kuning telur pada penelitian ini menunjukkan tidak terdapat pengaruh yang nyata $(\mathrm{P}>0,05)$ pemberian level protein ransum yang berbeda terhadap warna kuning telur. Tidak nyata pengaruh perlakuan terhadap warna kuning telur disebabkan komposisi jagung kuning dalam ransum tidak jauh berbeda. Pada perlakuan A (15\%), B (17 \%) dan C (19\%), masing-masing komposisi jagung yang dipakai adalah $62 \%$; $59,10 \%$ dan $53 \%$. Jadi perbedaan komposisinya hanya sebesar $9 \%$. Menurut North dan Bell (1990) warna kuning telur dipengaruhi oleh pigmen karotenoid yang terkandung dalam jagung kuning bahan pakan. Sebelumnya Romanoff (1963) menjelaskan bahwa unggas yang mengkonsumsi ransum yang mengandung karatenoid tinggi akan menghasilkan telur dengan intensitas warna kuning telur yang lebih tinggi

\section{Kesimpulan}

Berdasarkan hasil penelitian dapat disimpulkan bahwa peningkatan pemberian level protein ransum belum mempengaruhi secara nyata performa produksi ayam hasil persilangan arab dengan kampung pada periode layer. Pemberian level protein ransum $15 \%$ sudah dapat dihasilkan performa produksi yang baik, tetapi pemberian level protein $19 \%$ dapat menghasilkan performa produksi yang lebih tinggi.

\section{Daftar Pustaka}

Abbas, M.H.,1988. Ketahanan Usaha Ternak Ayam Ras dan Ayam Buras dibawah Tekanan Fluktuasi Harga Makanan dan Telur di Sumatera Barat. Proc. Seminar
Nas. Pengembangan Peternakan di Sumatera Barat.

Darmana, W. dan M. Sitanggang., 2002. Meningkatkan Produktivitas Ayam Arab Petelur. Agromedia Pustaka, Semarang.

Deptan, 1999. Pedoman Beternak Ayam Buras di Pedesaan. Tim Konsultan RRMC Proyek Produksi dan Pengembangan Ayam Buras, Jakarta

Dudung, 1990. Memelihara Ayam Kampung Sistim Batery. Penerbit Kanisius, Jogyakarta.

Jasman, 1989. Pengaruh Tingkat Protein terhadap Hen Day Ayam Buras Petelur. Skripsi. Fakultas Peternakan Universitas Andalas Padang, Padang

North, M.O. and Bell, 1990. Commercial Chicken Production Manual. The $4^{\text {th }}$ Ed. Chapman and Hall, New York.

Oleyemi, J.A. and F.A. Roberts,. 1979. Poultry Production in Warm Wet Climate. The Macmillan Press Ltd, London.

Romanoff, A.L. and A.J. Romanoff., 1963. The Avian Egg. Jhon Willey and Sons. Inc New York.

Sarwono, 2001. Ayam Arab Petelur Unggul. Penebar Swadaya, Jakarta.

Sudaryani, T dan Santoso. 1994. Pembibitan Ayam Ras. Penebar Swadaya, Jakarta.

Steel , R.G.D. and J.H. Torrie. 1995. Prinsip dan Prosedur Statistika 
Suatu Pendekatan Biometrik. Wahju, J. 1992. Ilmu Nutrisi Unggas.

Gramedia, Jakarta. Edisi Revisi. UGM Press, Jogyakarta.

Alamat korespondensi: Husmaini

Jurusan Produksi Ternak, Fakultas Peternakan

Universitas Andalas, Kampus Limau Manis, Padang

Telp. 0751-74208 Fax: 0751-71464, HP: 08126736590

Artikel diterima: 28 Januari 2006, disetujui: 1 Februari 2006 